\title{
Commitment and Poetic Justice: Irish Republican Women's Prison Writing
}

\section{Fiona McCann}

\section{(2) OpenEdition \\ 1 Journals}

Electronic version

URL: https://journals.openedition.org/ces/4962

DOI: $10.4000 /$ ces.4962

ISSN: 2534-6695

Publisher

SEPC (Société d'études des pays du Commonwealth)

\section{Printed version}

Date of publication: 1 September 2015

Number of pages: $57-66$

ISSN: 2270-0633

\section{Electronic reference}

Fiona McCann, "Commitment and Poetic Justice: Irish Republican Women's Prison Writing",

Commonwealth Essays and Studies [Online], 38.1 | 2015, Online since 10 April 2021, connection on 10 July 2021. URL: http://journals.openedition.org/ces/4962 ; DOI: https://doi.org/10.4000/ces.4962

\section{(c) $(1) \odot$}

Commonwealth Essays and Studies is licensed under a Licence Creative Commons Attribution - Pas d'Utilisation Commerciale - Pas de Modification 4.0 International. 


\section{Commitment and Poetic Justice: Irish Republican Women's Prison Writing}

This article focuses on prose and poetry produced by Irish republican women prisoners either during their time in prison or after their release, and aims to investigate the ways in which they, on the one hand, represent acts of gendered violence and torture at the hands of prison guards and, on the other, interrogate their solidarity as a group of women. It will be suggested, through close analysis of the tropes deployed, that their commitment, as it is expressed in this writing, moves beyond militant republicanism to embrace a feminist dimension.

The relative dearth of critical attention to contemporary Irish republican prison writing raises important questions about what kinds of literatures are deemed worthy of study in both academic and mainstream contexts. If a few Irish prison memoirs, notably those by Gerry Adams and Danny Morrison, or Countess Markievicz's prison letters, have elicited some critical response, the poetry and prose produced by republican prisoners incarcerated during the late twentieth century Troubles has been little explored, apart from studies by Lachlan Whelan and David Lloyd. Perhaps this is because the North of Ireland already boasts so many award-winning poets whose work indisputably deserves sustained attention and analysis. But it is potentially also symptomatic of a certain malaise in dealing with poetry that cannot be separated from the conditions of its production and of a reluctance to place Irish republican prison protests and poetry in the same realm. Poetry, it seems, should not be too political. ${ }^{1}$

In this article, which is part of a larger project on writings by political prisoners in various conflict/post-conflict zones (Uganda, Nigeria, South Africa), I would like to propose an analysis of some Irish republican prison writing produced between the 1970s and 1990s and to consider how the experience of incarceration, aggravated by the often inhuman conditions to which the prisoners were exposed, shaped the emergence of an aesthetics specific to these circumstances. I agree with Peter Shirlow and Kieran McEvoy that "Republican prisoners [...] saw themselves as actors who were builders of history via collective action" and that "throughout the 1980s and 1990s, the vocabulary of collective action gradually shifted towards the language and privileging of conflict transformation," (Shirlow \& McEvoy 145) and I suggest that this shift in attitude is best expressed in creative writing undertaken by the prisoners. In the writing produced during this period, this change in attitude is nowhere more apparent than in the issues of An Glór Gafa/The Captive Voice, a quarterly magazine established in 1989, written and edited entirely by republican prisoners detained in Ireland, England, continental Europe and the US, and which published (an ironic) 26 issues in all. What emerges in

1. Edna Longley, the doyenne of critical thinking on Irish literature and a specialist in Irish poetry, criticises every aspect of republicanism and is particularly scathing of republican writing and Ireland's postcolonialism, and full of disingenuous remarks towards the few critics who write about either (see Longley 30-33). Longley is fond enough of poets from the North such as Seamus Heaney, Derek Mahon, Paul Muldoon, and Michael Longley (among others) as long as republican politics do not come bubbling too close to the surface. She is not alone in this, which explains a reluctance to engage with the significant enough body of republican prison poetry. My point here is that although there is an acceptance that poets may be political (although not too republican), there is no real acceptance of the fact that paramilitaries, or actors in the conflict, may be poets. 
these issues is a clear interrogation of all forms of oppression (from the usual suspects of the British state and establishment who inevitably loom large, to oppression within the republican movement itself of women and LGB volunteers, as well as reflections on other conflict/post-conflict zones) and an awareness that the equal society being fought for has as much to do with tackling issues such as paedophilia, substance-abuse and reproductive rights as with eradicating British presence in the six counties known as Northern Ireland. The question of commitment in the writing under scrutiny here is therefore multiple and embraces commitment to (and beyond) the ideals of the republican movement, as well as to feminism and literary creation.

The forms of writing which appear in An Glór Gafa are multiple and range from factual articles on the war being fought and on a wider, international context of resistance movements, to Irish lessons and crosswords, and from prison anecdotes to poems and short stories, complete with illustrations. This means that when working on prison writing, it is necessary to break down any rigid barriers which would separate politics from aesthetics, since each prisoner who writes chooses the medium (sometimes more than one), and therefore the aesthetics, s/he deems best suited to his/her endeavour. Thus we are constantly being pushed to suspend or expand the evaluative grids dear to literary scholars and to search for others.

In spite of the huge body of work written by Bobby Sands, this article will not deal with his poetry and prose which I have written about elsewhere (McCann), but will, in an attempt to uncover other unheard voices and question stereotypical ideas about republican women's imprisonment and the reasons for their military involvement in the conflict, focus on poetry and prose written by women prisoners. I aim to show how these prison narratives constitute on the one hand powerful forms of personal and group resistance and, on the other, points of departure for an analysis of the role of storytelling and poetry-writing in prison contexts as a means of survival and consciousness-raising. The rawness of the material under study should not, I shall argue, eclipse its aesthetic value and should instead lead us to elaborate different prisms through which to read it.

As Fionnuala Ní Aoláin, Dina Francesca Haynes and Naomi Cahn point out,

[w] omen who identify strongly as political actors and wish to avoid being categorised as victims (despite experiences of harm), often choose not to appear before truth or accountability processes in post-conflict societies. If or when they do, they will not define their experiences as falling within the terminology of victim-hood. (Ní Aoláin, Haynes \& Cahn 44)

Most of the creative and factual pieces produced by women republican prisoners in $A n$ Glór Gafa sustain this claim, as do various poems and letters published in a collection of stories of former republican women prisoners entitled In the Footsteps of Anne (Brady et al. 2011). ${ }^{2}$ However, notwithstanding their frequent reaffirmation of commitment to republicanism, many women prisoners also give expression to the various forms of violence to which they are subjected both at the hands of both prison wardens and in their own personal lives.

2. Although it was hotly debated, the idea of a truth commission in the North of Ireland was eventually sidelined. However, the relative dearth of memoirs produced by former women prisoners, even taking into account their numerical inferiority, seems to suggest an unwillingness to dwell on this experience, although the few memoirs produced do uphold Ní Aoláin, Haynes \& Cahn's claim that women do not like to present themselves as victims. See for example Darragh. 
The recent publication of In the Footsteps of Anne is significant as it allows, for the first time, multiple women prisoners' voices, often dwarfed by those of their male counterparts, to be heard. The editors stipulate in their introduction that "there are many women who have been written out of history and their stories will never be told," (Brady et al. 15) and they underline the reticence of many women to speak of their experiences (14). ${ }^{3}$ The book started out as a project undertaken by former OC Eileen Hickey in response to the interest expressed by a group of Dublin academics in publishing former IRA women prisoners' stories. It was important for Hickey that the women involved should "have ownership of this project" (Brady et al. 13) and she also states unequivocally that the assembled stories are "not to be used as a party political propaganda tool by any political party," (12) an affirmation which indicates her wish to avoid the kinds of controversy surrounding Bobby Sands' literary estate/the Bobby Sands Trust and the co-optation of these stories by the well-oiled machinery of the Sinn Féin publicity office.

The poetry and prose published both in this volume and in An Glór Gafa/The Captive Voice are, like that of Bobby Sands, uneven in quality and somewhat raw. In the recent collection, In the Footsteps of Anne, few of the contributors choose to express themselves through poetry, whereas this form is much more prominent, although often anonymous, in An Glór Gafa/The Captive Voice. While a good deal of the accounts in Footsteps predictably pay tribute to male comrades-in-arms, particularly as regards the 1981 hunger strike, ${ }^{4}$ overall there is precious little mention of any men, the emphasis clearly placed on the strong links binding the women. What is particularly striking is the recourse to euphemism when difficult subjects are broached. For instance, one former prisoner, Mary Robinson, evokes sexual assault she experienced at the hands of a female prison warden which she describes as follows: "I soon learned to rise quickly because the female screw who woke me for each court appearance liked to try to touch me in a way which was not nice or appreciated. I would have expected this type of behaviour from a male screw but that was too much, if you get my drift" (Footsteps 152). Although this may potentially be read as vaguely homophobic, I would suggest that it is simply because sexual assault by another woman is beyond the bounds of what is "expected" even within this violent prison universe that the experience must be couched in periphrases, negation and idiomatic expression. It is worth pointing out that the

3. Louise Henaff, of a France Culture documentary, La Fabrique de l'histoire, on women republican prisoners had great difficulty finding former prisoners who wished to speak of their experiences.

4. The British government introduced legislation which meant that prisoners convicted of "terrorist" offences after March 1st 1976 would no longer be considered as political prisoners, a status which had been won by hunger strike in 1972. Refusing to be criminalised, male republican prisoners refused to wear the prison uniform and were given blankets to cover themselves. So began the blanket protest. Over the next two years, tensions between prisoners and prison wardens increased as the former refused to accept the new regime (refusing to carry out mandatory prison work, for example) and the authorities responded by refusing remission for those on protest, and severely limiting contact between prisoners and those outside. The situation escalated in April 1978 into a no wash protest during which prisoners covered the walls of their cells with their excrement and when the British government still refused to give in to the five demands (the right not to wear a prison uniform, not to do prison work, the right to free association, to one letter, parcel, and visit per week, and the restoration of full remission), the prisoners began a hunger strike in 1980 which ended amid some confusion around alleged British promises which were later denied by the latter. A second hunger strike in 1981 ended in the death of ten prisoners before families intervened to feed their loved ones. These protests took place in the men's prison, Long Kesh/H Blocks. The situation was slightly different in the women's prison in Armagh in that they were allowed to wear their own clothes, but they too began a no wash protest and hunger strike in response to violent treatment by male and female prison wardens. For further information on this period and on the prison struggle, see Beresford, Darragh, McKeown and Morrison, among many others. 
male prisoners in Long Kesh/H Blocks, although they described abuse in some detail, were reluctant enough to refer to the sexualised nature of it. One notable exception is a laconic remark by Bobby Sands in a letter to Liam Óg: after giving the names of prisoners who "all were fired over a table and the cheeks of their behinds torn apart by the screws' hands," he adds, "Comrade, this is sexual assault" (Beresford 52). It is also noteworthy that when other forms of physical violence and intrusion upon their bodies are mentioned, a preference for the passive voice can be observed, as in the above description by Sands or in Marian Price's account (written in a letter to her parents while she was in prison and just two days after the event) of being force fed while on hunger strike:

I was pulled off my bed and carried bodily by the arms and legs from my cell to the room where it takes place. I was put in a chair, my legs were held and my arms put up my back and held tightly. My head was then bent and my nostrils choked in an attempt to make me open my mouth. I opened my lips to breathe but clenched my teeth. Pressure was put on my chin a number of times to make me open my mouth but I managed to keep it closed. I was then blindfolded and a metal clamp was used to force my teeth apart. This was screwed in place; the wooden gag was inserted and the blue tube pushed into my stomach. After the liquid had been poured in, the clamp and the gag were removed, and then the blindfold and I was then practically carried back to my cell. (Footsteps 129)

The repeated use of the passive here, as each action is mechanically described through parataxis, and the palindromic effect of each action then being undone, works to reinforce the extent of the violence, as the agents (literally the agents of the state) are elided, appearing all the more sinister in their anonymity. The attempted though unsuccessful resistance is strengthened in the two sentences in which Marian Price is the agent ("I opened my lips"; "[I] clenched my teeth"; "I managed to keep it closed") sandwiched as they are between the violent restrictions to which she is subjected, while the elision of the actual moment of force feeding and her physical response to it presents it as a sort of hollow victory for her oppressors.

Finally, in terms of encroachments upon women prisoners' bodies, the widespread practice of strip-searching, even well after they ended in the H Blocks, is referred to euphemistically again and again in Footsteps as so many incidents of sexual assault. This practice is perhaps the most symbolic distinction between the male and female prisoners' experiences in prison, particularly because strip searches were carried out even once Armagh Gaol closed and the prisoners were transferred to Maghaberry, regardless of pregnancy or menstruation, and frequently in the presence of male prison wardens (see Corcoran 51-7; Moore \& Scraton 88-91). One of the frankest descriptions of this practice is that given by Jennifer McCann:

During the strip-search they would have put a towel around your head so you could not see who was doing the search and could not identify the screws that were searching you. They literally spread-eagled you and held you down on the floor and ripped the clothes from your back. The remand prisoners were going through this on a weekly basis and it was just humiliating and traumatising. I know that many women's periods stopped for months as it was so traumatising. (Footsteps 210-1)

The use of the generic "you" in this description creates a distancing effect similar to that of the passive voice in Marian Price's description of force-feeding, yet the recourse to polysyndeton establishes a sense of the relentlessness of the violence, itself reinforced by the violent verb "ripped." Jennifer McCann is one of the few women to speak 
openly of trauma and although none of the women actually use the word "torture," this is clearly what is going on. Lest there should be any doubt about this, it is useful to recall Elaine Scarry's seminal discussion of "the body in pain" and in particular the chapter she devotes to clarifying the differences between torture and war: she argues that while soldiers may choose to fight (this is certainly the case of the republican volunteers imprisoned in Armagh), "the prisoner of torture has at no time consented to contribute his [or her] body to the fiction of the regime's power produced through his [or her] pain" (Scarry 144). Jennifer McCann's reference to prisoners' menstrual cycles and their cessation as a side-effect of the dehumanisation of the prisoners (they are quite literally defeminised) is not an isolated one; many other women mention feelings of degradation as they are required to remove their menstrual protection and have it inspected and commented upon, along with their clothes and underwear. This is all the more significant because, as Aretxaga points out, women volunteers within the IRA "had consciously rejected gender as a differential factor in political militancy," an attitude which involved "prov[ing] that gender was irrelevant to military performance in a male organization [... by] downplaying women's difference and interiorising men's standards" (Aretxaga 138). Prison wardens' deliberate exploitation of the women prisoners' menstruation was a clear example of the "procedures for the individual and collective coercion of bodies" highlighted by Foucault in his seminal work on prisons (Foucault 169). It is a classic example of how "discipline" as defined by Foucault "is a type of power, a modality for its exercise, comprising a whole set of instruments, techniques, procedures, levels of application, targets" (Foucault 215). The prison wardens' actions are a case of converting pain "into the fiction of absolute power" through "an obsessive, self-conscious display of agency" (Scarry 27). This emphasis on the torturers' agency also partially explains the political gesture hidden in Marian Price's decision to use only passive structures precisely so as to undermine this "self-conscious display of agency."

Similar preoccupations emerge in the poetry produced by these prisoners. In an anonymous poem published in An Glór Gafa/ The Captive Voice, one prisoner returns to this question of torture in sparse, raw lines of poetry. The poem is entitled "Alone":

By yourself, alone with your dread

but not for long

you had the company

eight in all

held you down

we couldn't hear you

calling for us

each individually

but we share

we share your anger

although spared

the degradation

this time,

each of us

individually

comfort you

our comradeship

consoling you

each of our hands 
making a fist

showing our white knuckles

our strength

and our sisterhood. (An Glór Gafa/ The Captive Voice 1994, 9)

The very typography and sparsity of the poem, notably present in the prevalence of monosyllabic words and extremely short lines of varying metre, ${ }^{5}$ reflect the central issue explored here: that of the isolation of prisoners ("Alone / By yourself") in order to better overpower and humiliate them, a process well documented by David Lloyd (Lloyd 166-97). A whole series of ironies pervade the poem, notably through the polysemous use of the word "company" which simultaneously suggests companionship and a military structure, only to then make clear that the unwanted company in question is that of the prison wardens carrying out a violent strip-search. The poem in fact foregrounds the tension between the individual and the collective and that between solitude and belonging. This is evidenced in the alternating second person singular and plural pronouns and the multiple enjambments: "held you down / we couldn't hear you"; "our comradeship / consoling you / each of our hands / making a fist" (emphasis added). The bitter irony of the solitude of the prisoner being relieved by the brutal "company" of eight prison wardens is underlined in the ambiguity surrounding the unvoiced sexual violence of the scene ("eight in all / held you down") and then countered through the reassertion of the individual subjectivities of all the prisoners. The "you" is simultaneously a generic one and an individual one, just as the message of solidarity contained within the poem is an individual ("each of us / individually") and a collective one ("our sisterhood"), as evidenced by the first person plural pronoun used throughout. "Alone[ness]" or isolation then emerges as a strategy developed by the prison staff both to violate and to undermine the collective dynamic of the prisoners, yet the poem functions as a powerful celebration of collective resistance, not least in the iconic image of the clenched fist which, far from being a lazy cliché, places this struggle on a level equal to other resistance movements, aligning it with both nationalist and feminist struggles elsewhere. ${ }^{6}$ One should also be wary of overlooking the fact that the poem was published anonymously in An Glór Gafa/The Captive Voice as, in the same manner as the numerous articles published in An Phoblacbt during the prison protests of the 1970s and 1980s by mostly male prisoners, this very much reinforces a group response as opposed to the elevation of individual voice and a commitment to a dynamic among women that transcends the republican movement. ${ }^{7}$

However, not all the poetry revolves around the evocation of the physical and emotional turmoil of prison, protest or institutionalised violence. Much of it is devoted to more personal issues, such as the growth from innocence to experience, or reflections on dysfunctional heterosexual relationships and a commitment to what might be ter-

5. The sparseness of this and other poems is also potentially gender specific. Bobby Sands' poetry for instance is often voluminous and florid.

6. This is reminiscent of the mural in the Upper Falls Road, now expunged, which depicts an IRA, a PLO and a SWAPO volunteer, all women, encircled by the symbol for Venus which has now become the symbol both for women and feminist movements. See Aretxaga 49.

7. It is also, of course, a means of making sure that no one prisoner will subsequently be victimised by prison staff for any publication, and that close relatives, or fellow volunteers, reading these journals will be unable to identify the author. It should be pointed out that even during the prison protests of the late 1970s and early 1980s, women prisoners were allowed to write and did not have to hide their written productions inside their bodies as the male prisoners did. Their writing, and the letters they received, were however subject to censorship. 
med feminist issues. The poem "Woman," published (also anonymously) in the same issue of An Glór Gafa/The Captive Voice as "Alone," despite the limited and essentialist perspective the title might at first glance suggest in its allusion to a generic woman, actually charts the breaking out of a restrictive understanding of womanhood and of an oppressive heterosexual relationship:

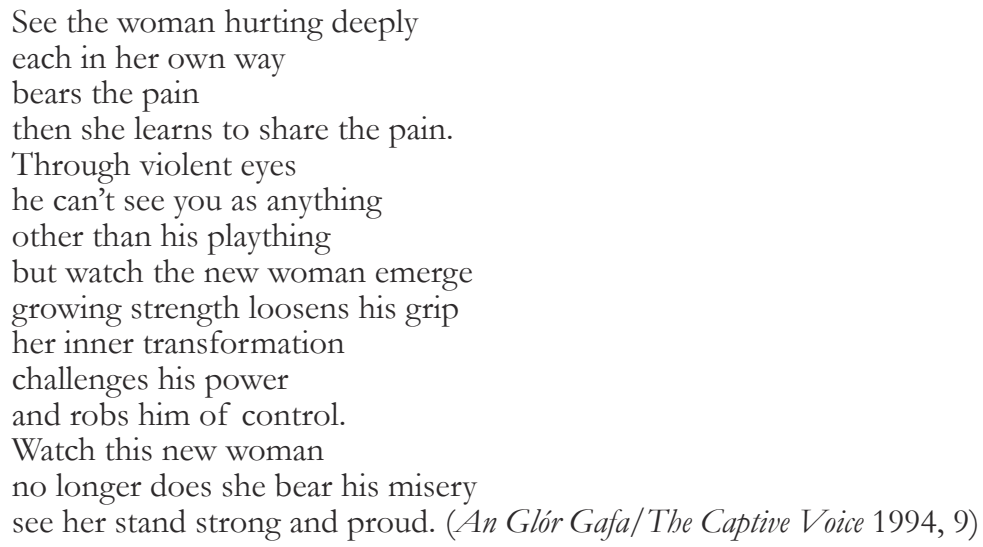

The apparent generic woman of the title immediately becomes an individual one in the poem's opening line, and is just as quickly extended to include all the women within the republican movement in all their individual subjectivities ("each in her own way"). The anaphoric presence of the imperative "see" urges the reader to acknowledge their pain and to visualise these women not as victims of men's whims, but as powerful figures in their own right, especially since a comparison of the first and final lines of the poem invites us to acknowledge the sea-change which has occurred. Collective solidarity is also once again foregrounded in the internal rhyme ("bear the pain"; "share the pain") and there is an obvious and somewhat ironic pun on the "new woman" who emerges in the second half of the poem, since this "new woman" is emerging more or less a century after her archetypal predecessor. This is, in itself, an oblique acknowledgement of the failures of the republican movement to capitalise on the strong involvement of many women, politically and militarily, between 1916 and the end of the Civil War in 1923. Because of the recourse to generic terms and allusions to archetypes, it is difficult not to read this bastardised sonnet as an acerbic commentary on attitudes to women volunteers within the republican movement, not always taken seriously and perceived as mere "playthings" or outlets for the men's "misery." The "inner transformation" then becomes both the growth in strength of the woman and the experience of incarceration, being on the inside, the place which, through solidarity among the women prisoners, allows this "transformation" to take place. That they refuse to "bear his misery" is of course also significant as it constitutes an overt rejection of and refusal to incarnate the mater dolorosa figure dear to republican iconography. What is sketched out in this short poem is therefore the contours of a new regime which rejects the "power" and "control" of men and male comrades and embraces the role that women can proudly play.

8. See also Aretxaga's comments on this metamorphosis in attitudes from perceiving women as maternal figures to acknowledging them as soldiers, particularly in iconography (Aretxaga 50-1). 
A second compelling and also anonymous poem published in an issue of the same journal specifically devoted to women's issues, entitled "Growing Pains," also poignantly evokes the transition from girlhood to womanhood within the prison space:

Girl of teenage years, practising self-destruction,

for a few kicks and a false serenity.

Woman within pulls at the reins, scratches

the surface, chases the ghosts and makes an impression.

Girl of one million contradictions, head

overloaded with thoughts of how things should be.

Woman, umbilically bonded, bursts to surface,

head overloaded with concrete ideas of how things will be.

Girl of a long time ago, thoughts of tomorrow

killed the moment previously lived for.

Woman that is now, still one million contradictions,

with a path to walk on, it's not easy; the

right way never is. (An Glór Gafa/ The Captive Voice 1990, 8)

In many ways this poem, like the preceding ones, supports the important point made by Louise Ryan and Margaret Ward when they recall "the necessity to distinguish between how women have been represented in national histories and cultural and symbolic repertoires on the one hand, and, on the other, how they have actually negotiated and challenged their roles and contributions to nationalism." According to them, "[w]hile nationalist symbols, images and texts have continued to depict women within a narrow range of cultural stereotypes, women's roles within nationalism have been, and continue to be, diverse, multifaceted and dynamic" (Ryan \& Ward 3). This diversity is very much expressed in the above poem in which the "one million contradictions" which co-exist in her are twice evoked, and in which the temporal strata of past, present and future are intertwined.

Another bastardised sonnet, the poem "Growing Pains" reveals itself to be a complex reflection on coming-of-age and it is never really clear whether the eponymous "growing pains" signal the physical and psychological discomfort of growing from girl to woman or whether physical and psychological discomfort continue to grow because of the paramilitary and prison experience. The poem remains deliberately ambivalent on this question and plays on the tension between girlhood and womanhood, a tension which is expressed through a subtle change of modal - the girl is "full of thoughts of how things should be" while the woman is full of "concrete ideas of how things will be." This subtle shift suggests that the move from girlhood to womanhood is accompanied by a move from idealism to realism or pragmatism and this is given weight by the separation in the enjambment of "head" and "overloaded" in the case of the young girl (5-6), a separation which disappears when that same phrasing is used for the more mature speaker in line 8 . The shift from impetuous action to mature reflection is further enhanced in the association of youth and violence at both the beginning and the end of the poem: "Girl of teenage years, practising self-destruction"; "Girl of a long time ago, thoughts of tomorrow / killed the moment previously lived for." The second allusion to violence in particular seems to suggest that, having been seduced by idealism and thoughts of a better tomorrow (possibly even by republican propaganda), the "girl" has brutally sacrificed her youth and the nominal clause ("Girl of a long time ago") appears to be the call of the older, more mature prisoner to her younger, naive self. What subtends these reflections is a sense that in her youth, in an attempt to act like an adult, the 
girl has acted so as to "make an impression," but the elision of on whom or what this impression was to be made invites us to consider this ambivalence and to entertain the possibility that the younger girl wanted to "make an impression" on the political status quo and, quite literally, come into being, exist, which is why it was the "woman within" who urged her to act. The alternating couplets maintain a sort of dialogue between the girl and the woman, and the absence of rhyme underlines the discordance between the two. The absence too of any article, definite or indefinite, before "Woman" or "Girl" points towards a generic as well as specific scenario, lifting this experience beyond the personal and presenting it as a more universal one. A sense of wistfulness pervades the poem, which is not to say that the persona in any way overtly criticises the republican movement or her involvement within it, although the reference to "self-destruction" might indeed constitute a vague criticism. Rather, the poem evokes lost youth and perhaps obliquely responds to the tendency among male volunteers and prisoners to refer to "the girls" in Armagh or Maghaberry (or Durham in this case). A "[g]irl of teenage years" might enter the prison, but the experience transforms her into a "woman" capable of reappraising the impetuousness of youth and at peace with her "one million contradictions," in spite of which "a path to walk on" nevertheless stands out. However, whether the path in question is a psychological or political one is not resolved by the end of the poem.

As I have tried to intimate, it is time that the voices of former Irish women political prisoners be heard as loudly as those of their male counterparts, as they provide nuanced and multi-faceted reflections on commitment to the republican movement and also to a wider feminist agenda. Laurence McKeown's otherwise stimulating work based on his doctoral thesis on the social construction of an Irish republican prisoner community barely even mentions the involvement of women volunteers and prisoners, ${ }^{9}$ yet all of the women whose stories appear in Footsteps and whose prose and poetry appear in the various issues of An Glór Gafa/The Captive Voice raise important and complementary issues about the gendered experience of incarceration as political prisoners. As Linda Moore and Phil Scraton point out, "[s]ince the development of the modern prison system, women's imprisonment has been marginalized within a penal system aimed at male prisoners under the direction of male managers and staffed by male guards." They also emphasise that the history of women's imprisonment is "also a history of subjugation to gendered punishments and sexual abuse" (Moore \& Scraton 24), a fact which is borne out in the writing under discussion here. This article has not addressed the many means by which women republican prisoners resisted "the social construction of gender, derived in expectations that incorporate what is considered 'acceptable' behaviour" and its "significant impact on women's incarceration" (Moore \& Scraton 25), but it has highlighted how writing personal accounts, letters and poems enabled many women prisoners to act on "the imperative to narrate that exists in the telling or recounting of being tortured [an imperative which] stands as an attempt to subvert one of the primary functions of torture itself" (Taleghani 122). The prison literature analysed here was produced, for the most part anonymously, by women prisoners whose commitment to republicanism, feminism, the family, and the community, notwithstanding the work

9. This is no doubt partly due to the fact that his study is based on the experience of prisoners in the male prison of Long Kesh/H Blocks. 
carried out by the Prison Memory Archive, ${ }^{10}$ all too often remains unheard. They have become what former prisoner Sile Darragh calls "ghosts on that wing" (Darragh 142). It is hoped that this article goes some way to making these voices, and their intense sense of commitment, more audible.

Fiona McCANN

Université de Lille

\section{Works Cited}

AnGlór Gafa/ The Captive Voice 2. 2 (Summer 1990).

AnGlór Gafa/ The Captive Voice 4. 1 (Spring 1994).

AretXaga, Begoňa. Shattering Silence: Women, Nationalism, and Political Subjectivity in Northern Ireland. Princeton, NJ: Princeton UP, 1997.

Beresford, David. Ten Men Dead. London: Harper Collins, 1994.

Brady, Evelyn, Eva Patterson, Kate McKinney, Rosie Hamili, and Pauline Jackson, eds. In the Footsteps of Anne: Stories of Republican Ex-Prisoners. Belfast: Shanway P, 2011.

Corcoran, Mary. Out of Order: The Political Imprisonment of Women in Northern Ireland 1972-1998. Portland, O: Willan, 2006.

Darragh, Síle. "John Lennon's Dead": Stories of Protest, Hunger Strikes \& Resistance. Belfast: Beyond the Pale, 2011.

Foucault, Michel. Discipline and Punish: The Birth of the Prison. Trans. Alan Sheridan. London: Penguin, 1977.

LLOYD, David. Irish Culture and Colonial Modernity 1800-2000: The Transformation of the Oral Space. Cambridge: Cambridge UP, 2011.

Longley, Edna. The Living Stream: Literature and Revisionism in Ireland. Newcastle: Bloodaxe, 1994.

McCann, Fiona. "Embodying Resistance: The Poetry of Bobby Sands." Études irlandaises 40.1 (Printemps-été 2015): 325-37.

McKeown, Lawrence. Out of Time: Irish Republican Prisoners. Long Kesh 1972-2000. Belfast: Beyond the Pale, 2001.

Moore, Linda, and Phil Scraton. The Incarceration of Women. Basingstoke: Palgrave Macmillan, 2014.

Morrison, Danny, ed. Hunger Strike: Reflections on the 1981 Hunger Strike. Dingle: Brandon, 2006.

Ní Aoláin, Fionnuala, Dina Francesca Haynes, and Naomi CAHn. On the Frontlines: Gender, War, and the Post-Conflict Process. Oxford: Oxford UP, 2011.

SCARRY, Elaine. The Body in Pain: The Making and Unmaking of the World. Oxford; New York: Oxford UP, 1985.

ShirLow, Peter, and Kieran McEvoy. Beyond the Wire: Former Prisoners and Conflict in Northern Ireland. London: Pluto P, 2008.

Taleghani, R. Shareah. "The Cocoons of Language: Torture, Voice, Event." Human Rights, Suffering, and Aesthetics in Political Prison Literature. Ed. Yenna Wu, and Simona Livescu. 2011. New York: Lexington Books, 2013. 117-38.

Whelan, Lachlan. Contemporary Irish Republican Prison Writing: Writing and Resistance. Basingstoke: Palgrave Macmillan, 2007.

10. The Prison Memory Archive (PMA) is an ongoing project based in the North of Ireland which works at recovering the stories of prison wardens, inmates and families of inmates who were imprisoned during the Troubles. Based on a politics of storytelling as a means of recovering from the prison experience, the process is explained thus: "Drawing on the oral-history tradition of life-storytelling, with its open ended approach as opposed to leading questions, the PMA attempts to minimise the levels of mediation between participant and filmmaker and viewer. Participants were brought back to the empty sites of the Maze and Long Kesh Prison and Armagh Gaol, where a fifteen minute briefing before the recording discussed the process and what issues they wished to cover. A single camera operator, using a handheld camera and a radio microphone, followed participants as they walked and talked around the site. The sites' architecture and artefacts influenced the participants' structuring of remembering and helped trigger their memories according to what they encountered." For more information, see the PMA website: http://prisonsmemoryarchive.com/ 